\title{
MYOCARDIAL INFARCTION DURING SERUM SICKNESS
}

BY

\author{
N. J. ROUSSAK \\ From Crumpsall Hospital, Manchester
}

Myocardial infarction during serum sickness has been reported several times. In the following case the patient was a young man with no other evidence of heart disease and no family history of coronary disease.

\section{Case Report}

A bus-fitter, aged 36 years, was given tetanus antitoxin for a cut finger; a similar injection had been received twelve years previously without reaction. Seven days later a general urticarial rash appeared, and two hours later he felt faint and fell to his knees. He went to bed and slept for six hours, waking with pruritus and mild præcordial pain; after a subcutaneous injection of adrenaline the pain became more intense and radiated to the left arm.

On admission to Crumpsall Hospital one hour later, he had general urticaria, and profuse sweating, and was suffering constricting præcordial pain of a severity requiring morphine. There were no abnormal cardiovascular findings; the blood pressure was 140/70. Arthritis, lymphadenopathy, and albuminuria were absent.

Serum sickness and myocardial infarction were diagnosed and anticoagulant therapy started, together with cortisone $100 \mathrm{mg}$. daily by mouth for four days and then $50 \mathrm{mg}$. daily for three days. An electrocardiogram taken on the day following the onset of pain (Fig. 1) showed changes characteristic of extensive acute myocardial infarction, and later records were consistent with the normal evolution of the infarction. Radiograms of the heart and lungs, taken soon after admission to hospital and repeated after one month, showed no abnormality. Heterophile antibodies, absorbed by both guinea-pig kidney and ox red cells, were present in the serum to a titre of 1 in 112. Eosinophilia was not found. The serum cholesterol level was $195 \mathrm{mg}$. per $100 \mathrm{ml}$.

There was no pain after the first day, the blood pressure did not fall and recovery was good. Three months after the infarction the patient was back at work without disability.

\section{Discussion}

The coincidence of the myocardial infarction with the cutaneous manifestations of serum sickness, in a young adult without personal or family history of coronary disease strongly suggests that the allergic state played a part in initiating the infarction. It is interesting to note that the patient had had an urticarial eruption during penicillin treatment two years previously. There was no family history of allergic disorder.

There are five reports of myocardial infarction coinciding with serum sickness after tetanus antitoxin (J. Amer. med. Ass., Queries and Minor Notes, 1938; Boas, 1942; Mathieu et al., 1947; McManus and Lawlor, 1950; Heintz, 1951). All the patients were men and four were under 50 years of age (the age of the fifth was not stated). Two had had negative intradermal tests. Four patients developed the myocardial infarction and skin rash one week after injection of the antitoxin but in one they appeared on the day following the injection. The early onset in this patient may perhaps have been due to the patient's having received antitoxin previously with slight reactions. Three of the patients died and post-mortem confirmation of the diagnosis was 
obtained; in the other two the diagnosis was confirmed cardiographically. Since all the reported cases have been men over thirty years of age it is possible that latent coronary arterial disease was already present and predisposed to infarction. Even so, the coincidence of myocardial infarction with serum sickness suggests that this may be a precipitating factor, possibly causing an acute arteritis.

As well as overt myocardial infarction, prophylactic administration of tetanus antitoxin has been followed by urticaria, præcordial pain, and temporary abnormalities in $T$ waves over the

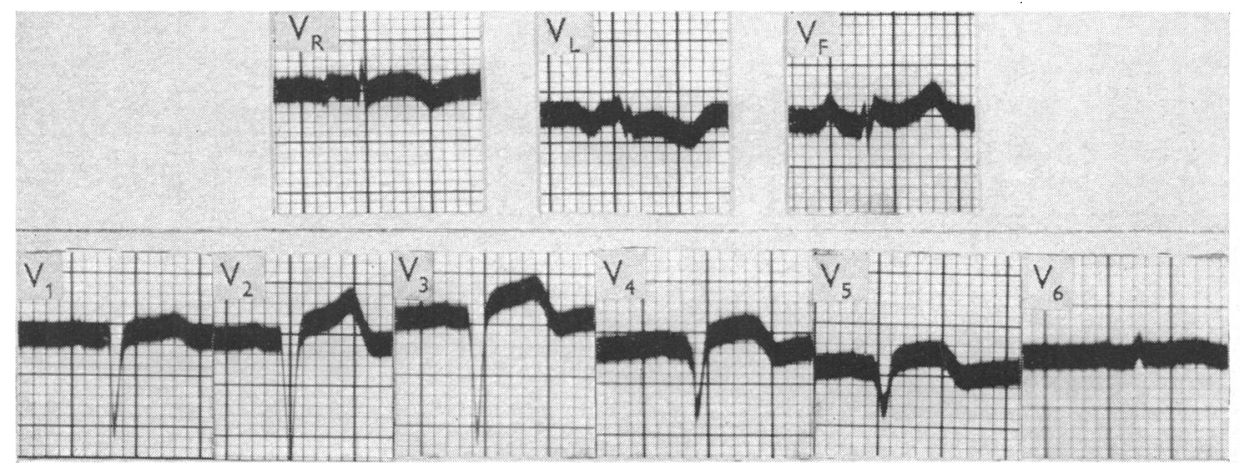

FIG. 1.-Præcordial leads taken the day following the onset of the pain.

precordium (Gulotta, 1951), and by typical angina pectoris (Vesell, 1937; Mathieu et al., 1947). Other cardiovascular sequelæ have also been noted, including carditis (Wadsworth and Brown, 1940), pericarditis and pleurisy (McKinlay, 1948), and death from generalized necrotizing arteriolitis (Berblinger, 1950).

Injections of sera other than tetanus antitoxin have also caused cardiovascular lesions. Myocardial infarction has occurred in fever therapy with T.A.B. (Lockart, 1939), and Stokes-Adams attacks in serum sickness due to antistreptococcal serum (de Lavergne et al., 1927). The histological appearances in three patients dying from pneumonia and poliomyelitis who received serum therapy and showed signs of hypersensitivity during life were fully described by Clark and Kaplan (1937) and by Clark (1938). Histiocytic proliferation in the endocardium and intima of aorta and coronary arteries, with interstitial myocardial infiltration, was found; necrotizing arteritis of the smaller coronary arteries was a prominent feature in one case. Similarly, lesions typical of polyarteritis nodosa, and sometimes eosinophilic myocarditis, were found by Rich (1942) in patients dying after receiving large doses of horse and rabbit serum for pneumonia and meningitis. Comparable lesions were later produced experimentally (Rich and Gregory, 1943), including lesions of coronary arteries (Rich and Gregory, 1947).

The introduction of foreign protein into the body by means of a wasp-sting has also been followed by myocardial infarction and angioneurotic odema (Milne, 1949).

Lastly, the coronary arteries may be affected in reactions due to drugs. Thus, penicillin has been held responsible for myocardial infarction (Pfister and Plice, 1950) and also for inversion of the $\mathrm{T}$ waves without symptoms of myocardial ischæmia, associated with arthritis and urticaria (Binder et al., 1950; Felder and Felder, 1950). Patients who invariably had anginal pain with inversion of the $T$ waves after ingestion of acetylsalicylic acid were described by Shookhoff and Lieberman (1942).

Since cortisone therapy appears to be of value in allergic states, including polyarteritis nodosa, its administration in serum sickness seems rational in the hope of preventing or minimizing possible cardiovascular lesions.

It is a pleasure to thank Dr. A. Morgan Jones and Dr. R. W. Luxton for their advice and criticism. 


\section{REFERENCES}

Berblinger, W. (1950). Virchows Arch., 318, 155.

Binder, M. J., Gunderson, H. J., Cannon, J., and Rosove, L. (1950). Amer. Heart J., 40, 940.

Boas, E. P. (1942). Amer. Heart J., 23, 1.

Clark, E. (1938). J. Amer. med. Ass., 110, 1098.

Clar, and Kaplan, B. I. (1937). Arch. Path., 24, 458.

Felder, S. L., and Felder, L. (1950). J. Amer. med. Ass., 143, 361.

Gulotta, C. J. (1950-51). New Orleans Med. and Surg. J., 103, 469.

Heintz, R. (1951). Z. KreislForsch., 40, 40.

J. Amer. med. Ass. (1938). 111, 1316.

de Lavergne, V., Morel, and Jochum (1927). Bull. Soc. med. Hôp. Paris, 51, 1314.

Lockart, R. J. (1939). Brit. J. Derm., 51, 318.

McKinlay, C. A. (1948). Jl.-Lancet, 68, 61.

McManus, J. F., and Lawlor, J. J. (1950). New Engl. J. Med., 242, 17.

Mathieu, L., Hadot, S., and Hadot, E. (1947). Arch. Mal. Coeur, 40, 328.

Milne, M. D. (1949). Brit. med. J., 1, 1123.

Pfister, C. W., and Plice, S. G. (1950). Amer. Heart J., 40, 945.

Rich, A. R. (1942). Johns Hopk. Hosp. Bull., 71, 123. , and Gregory, J. E. (1943). Johns Hopk. Hosp. Bull., 72, 65.

Shockhoff, C., and Lieberman, D. L. (1933). J. Allergy, 4, 506.

Vesell, H. (1937). Discussion before N.Y. Path. Soc., Arch. Path., 24, 696.

Wadsworth, G. H., and Brown, C. H. (1940). J. Pediat. 17, 801. 